\title{
Kunta- ja eduskuntavaalien äänestysaktiivisuus kuntakoon mukaan
}

\section{JUSSI WESTINEN}

Kunta- ja eduskuntavaalien äänestysaktiivisuudesta yksilötasolla on jo pitkään piirtynyt vakiintunut ja tuttu kuva. Korkeasti koulutetut, ylemmät toimihenkilöt ja johtajat sekä iäkkäämmät ja hyvätuloiset äänestävät aktiivisemmin kuin matalasti koulutetut, työntekijät ja työttömät sekä nuoret ja pienituloiset. (Ks. esim. Borg 1996; Wass 2008; Wass ja Borg 2012; 2016.) Äänestysaktiivisuden tutkiminen makrotasolla käyttäen aggregoitua dataa on ollut harvinaisempaa kuin yksilötason analyysit (ks. kuitenkin esim. Borg ja Pikkala 2017; Pikkala 2015; Westinen ja Borg 2016).

Kuntavaaleja tutkittaessa on havaittu, että pienissä kunnissa asuvat ihmiset tuntevat usein äänestämänsä ehdokkaan henkilökohtaisesti, kun taas keskisuurissa ja suurissa kaupungeissa yhteys on etäisempi (ks. Borg 2017). Tämä tuo päätöksentekijät ja päätettävät asiat lähemmäs kuntalaisia. Osittain tästä syystä on luontevaa, että kuntavaaleissa korkea äänestysprosentti on korreloinut pienen kuntakoon kanssa (ks. Pikkala 2015). Eduskuntavaaleissa sen sijaan äänestetään Helsinkiä lukuun ottamatta yhden tai useamman maakunnan kokoisissa vaalipiireissä, ja pienten kuntien ehdokkaiden on vaikeampi tulla valituksi kuin vaalipiirin suurimpien kaupunkien ehdokkailla. Tästä syystä eduskuntavaalit ovat etenkin pienten kuntien äänestäjän näkökulmasta hyvin erilaiset vaalit kuntavaaleihin verrattuna.

Tässä artikkelissa tarkastellaan äänestysaktiivisuuden muutoksia kunta- ja eduskuntavaaleissa 2000-luvulla ja analysoidaan niiden taustalla vaikuttavia syitä. Lisäksi artikkelissa avataan kuntakoon ja puoluekannatuksen välistä yhteyttä. Aineistona on Tilastokeskuksen (2021a) virallinen vaalitietokanta.

\section{KUNTAKOON JA ÄÄNESTYSPROSENTIN VÄLINEN YHTEYS 2000-LUVUN KUNTA- JA EDUSKUNTAVAALEISSA}

Aluksi tarkastellaan, miten kuntakoko on ollut yhteydessä äänestysprosenttiin 2000-luvun kunta- ja eduskuntavaaleissa. Tällä vuosituhannella kuntaliitoksia on ollut runsaasti, eikä osaa kunnista ole enää olemassa. Saatavilla olevat vaalitilastot eivät siksi mahdollista kuntien asukasluvun käyttämistä muuttujana kulloisenkin kuntajaon ja vaalivuoden mukaan. Tästä syystä kunnan kokoa tarkastellaan jokaiselta vaalivuodelta kulloisenkin kuntakartan mukaisesti saatavilla olevan korvikemuuttujan (ns. proxy-muuttuja), äänioikeutettujen määrän, valossa. Kuntien kokosuhteet pysyvät hyvin pitkälle samoina tällä muuttujalla.

Taulukossa 1 tarkastellaan äänioikeutettujen määrän ja äänestysprosentin välistä korrelaatiota kuntatasolla vuosien 2000-2017 kuntavaaleissa ja 2003-2019 eduskuntavaaleissa. Taulukko osoittaa, että muuttujien välinen yhteys on ollut tilastollisesti merkitsevä jokaisissa kuntavaaleissa, mutta vain kerran juuri ja juuri tilastollisesti merkitsevä eduskuntavaaleissa 2000-luvulla. 
Kuntavaaleissa pieni äänioikeutettujen määrä korreloi korkean äänestysprosentin kanssa, joten muuttujien välinen korrelaatio on negatiivinen. Huomattavaa on, että vuoden 2017 vaaleissa korrelaatio oli aikaisempia vaaleja heikompi $(r=-0,19)$. Pieni äänioikeutettujen määrä ei liity siis korkeaan äänestysprosenttiin yhtä vahvasti kuin aikaisemmin. Eduskuntavaaleissa korrelaatio on ollut lähellä nollaa. Tosin vuoden 2019 vaaleissa yhteys oli 2000-luvulla ensimmäistä kertaa tilastollisesti merkitsevä: suuri äänioikeutettujen määrä korreloi hienoisesti korkean äänestysaktiivisuuden kanssa toisin kuin tyypillisesti kuntavaaleissa.

Taulukko 1. Äänioikeutettujen määrän ja äänestysprosentin välinen korrelaatio 2000-luvun kunta- ja eduskuntavaaleissa Manner-Suomessa (Pearsonin r)

\begin{tabular}{|c|c|c|c|}
\hline \multicolumn{4}{|c|}{ Korrelaatiokerroin (r) } \\
\hline Kuntavaalit & & kunta & \\
\hline 2000 &,$- 36^{* *}$ & 2003 &,- 07 \\
\hline 2004 &,$- 27^{* *}$ & 2007 &,- 02 \\
\hline 2008 &,$- 25^{* *}$ & 2011 & 10 \\
\hline 2012 &,$- 31^{* *}$ & 2015 &, 06 \\
\hline 2017 &,$- 19 * *$ & 2019 &, $12^{*}$ \\
\hline
\end{tabular}

Selite: Tilastollinen merkitsevyystaso: ${ }^{* *} \mathrm{p}<0,01,{ }^{*} \mathrm{p}<0,05$

Seuraavaksi tarkastellaan tarkemmin kuntakoon ja äänestysprosentin välistä yhteyttä kaksissa viimeisissä kunta- ja eduskuntavaaleissa. Näistä vaaleista kuntien asukasmäärä on saatavissa vallinneen kuntajaon mukaisesti. Analyysissa käytetään seitsemää kokokategoriaa, joista pienin on alle 5000 asukkaan kunnat ja suurin vähintään 180000 asukkaan kaupungit (näihin ns. kuusikkokuntiin kuuluvat kuusi suurinta kaupunkia eli Espoo, Helsinki, Oulu, Tampere, Turku ja Vantaa). Muiden kategorioiden koot on esitetty taulukossa 2.

Taulukossa 2 näkyvät vuosien 2012 ja 2017 kuntavaalien äänestysprosentit kuntakokokategorioittain Manner-Suomessa. Kuhunkin kuntakokoryhmään kuuluvien kuntien äänimäärät ja äänioikeutettujen määrät on laskettu yhteen ja niiden pohjalta on laskettu yhteinen äänestysprosentti. Äänestysprosentti oli vuoden 2012 kuntavaaleissa sitä alhaisempi, mitä suuremmasta kunnasta oli kyse. Poikkeuksena on se, että 100 000-179 999 asukkaan kunnissa on ollut pienempi äänestysprosentti kuin kaikkein suurimmissa, vähintään 180000 asukkaan kunnissa. Vuosien 2012 ja 2017 kuntavaalien välillä suurimpien kaupunkien äänestysprosentti kasvoi kolmella prosenttiyksiköllä. ${ }^{1}$ Samalla ne menivät äänestysprosentissa 20 000-179 999 asukkaan kaupunkien ohi. 
Taulukko 2. Äänestysprosentti vuosien 2012 ja 2017 kuntavaaleissa kuntakoon mukaan Manner-Suomessa (\%)

\begin{tabular}{lccc}
\hline Kuntakoko & $\begin{array}{c}\text { Äänestysprosentti } \\
\text { kuntavaaleissa 2012 }\end{array}$ & $\begin{array}{c}\text { Äänestysprosentti } \\
\text { kuntavaaleissa 2017 }\end{array}$ & $\begin{array}{c}\text { Muutos vuoden } \\
\text { 2012 kuntavaaleista }\end{array}$ \\
\hline Alle 5 000 asukasta & 65,7 & 63,9 & $-1,8$ \\
Väh. 5 000, alle 10 000 asukasta & 62,8 & 61,8 & $-1,0$ \\
Väh. 10 000, alle 20 000 asukasta & 61,4 & 60,4 & $-1,0$ \\
Väh. 20 000, alle 50 000 asukasta & 57,8 & 57,6 & $-0,2$ \\
Väh. 50 000, alle 100000 asukasta & 56,8 & 56,8 & 0,0 \\
Väh. 100 000 asukasta, alle 180 000 as. & 53,6 & 54,7 & 1,1 \\
Väh. 180 000 asukasta & 56,1 & 59,1 & 3,0
\end{tabular}

Selite: Eri kuntakokokategorioihin lukeutuvien kuntien määrät olivat seuraavat:

$\begin{array}{ll}\text { Vuoden } 2012 \text { kuntavaalit } & \text { Vuoden } 2017 \text { kuntavaalit } \\ \text { alle } 5000 \text { asukasta }(n=122) & \text { alle } 5000 \text { asukasta }(n=118) \\ 5000-9999 \text { asukasta }(n=79) & 5000-9999 \text { asukasta }(n=80) \\ 10000-19999 \text { asukasta }(n=46) & 10000-19999 \text { asukasta }(n=42) \\ 20000-49999 \text { asukasta }(n=36) & 20000-49999 \text { asukasta }(n=34) \\ 50000-99999 \text { asukasta }(n=11) & 50000-99999 \text { asukasta }(n=12) \\ 100000-179999 \text { asukasta }(n=3) & 100000-179999 \text { asukasta }(n=3) \\ 180000 \text {-asukasta }(n=6) & 180000 \text {-asukasta }(n=6)\end{array}$

Myös 100 000-179 999 asukkaan kaupungeissa äänestysprosentti kasvoi hieman (1,1 prosenttiyksikköä), mutta alle 20000 asukkaan kunnissa laski vähintään yhden prosenttiyksikön verran. Eniten laskua oli alle 5000 asukkaan kunnissa - miinus 1,8 prosenttiyksikköä. Tästä huolimatta alle 5000 asukkaan kunnissa oli yhä korkein äänestysprosentti vuoden 2017 kuntavaaleissa (63,9 \%). Kaikkinensa kuntakoon mukaiset erot siis tasoittuivat vuoden 2017 vaaleissa, mitä myös madaltanut korrelaatiokerroin taulukossa 1 indikoi.

Taulukossa 3 näkyy vuosien 2015 ja 2019 eduskuntavaalien äänestysprosentit kuntakokokategorioittain Manner-Suomessa. Kuhunkin kuntakokoryhmään kuuluvien kuntien äänimäärät ja äänioikeutettujen määrät on laskettu yhteen ja laskettu niiden pohjalta äänestysprosentti. Kuten taulukossa 1 ilmeni, eduskuntavaaleissa kuntakoon ja äänestysprosentin välinen korrelaatio on ollut lähes olematon. Taulukko 3 valaisee asiaa lisää. Ainoa selkeästi muista erottuva on vähintään 180000 asukkaan kaupunkien äänestysprosentti, joka oli 73,1 prosenttia vuoden 2015 eduskuntavaaleissa, kun kaikissa muissa kuntakokokategorioissa äänestysinto jäi alle 70 prosentin. Vuoden 2019 vaaleissa suurimpien kaupunkien äänestysprosentti nousi 75,2:een, ja ero seuraavammaksi korkeimpaan äänestäneiden osuuteen säilyi neljän prosenttiyksikön tuntumassa. Vuoden 2019 vaaleissa äänestysprosentti nousi kaikissa vähintään 10000 asukkaan kuntakokokategorioissa vähintään kaksi prosenttiyksikköä. Pienimmissä, alle 5000 asukkaan kunnissa se nousi vain 0,3 prosenttiyksikköä. 
Taulukko 3. Äänestysprosentti vuosien 2015 ja 2019 eduskuntavaaleissa kuntakoon mukaan Manner-Suomessa (\%)

\begin{tabular}{lccc}
\hline Kuntakoko & $\begin{array}{c}\text { Äänestysprosentti } \\
\text { eduskuntavaaleissa 2015 }\end{array}$ & $\begin{array}{c}\text { Äänestysprosentti } \\
\text { eduskuntavaaleissa 2019 }\end{array}$ & $\begin{array}{c}\text { Muutos vuoden } \\
\text { 2015 eduskuntavaaleista }\end{array}$ \\
\hline Alle 5000 asukasta & 69,4 & 69,7 & 0,3 \\
Väh. 5 000, alle 10000 asukasta & 69,3 & 70,7 & 1,4 \\
Väh. 10 000, alle 20000 asukasta & 69,4 & 71,5 & 2,1 \\
Väh. 20 000, alle 50000 asukasta & 69,3 & 71,4 & 2,1 \\
Väh. 50 000, alle 100000 asukasta & 67,6 & 70,2 & 2,6 \\
Väh. 100 000 asukasta, alle 180 000 as. & 68,0 & 70,1 & 2,1 \\
Väh. 180 000 asukasta & 73,1 & 75,2 & 2,1
\end{tabular}

Selite: Eri kuntakokokategorioihin lukeutuvien kuntien määrät olivat seuraavat:

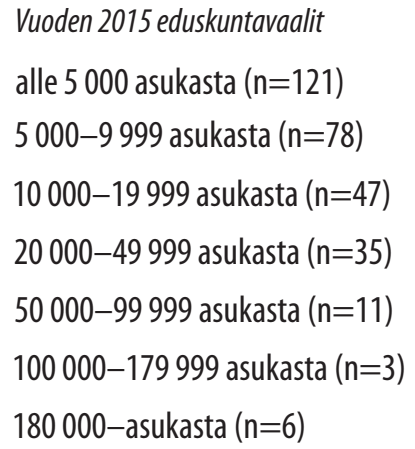

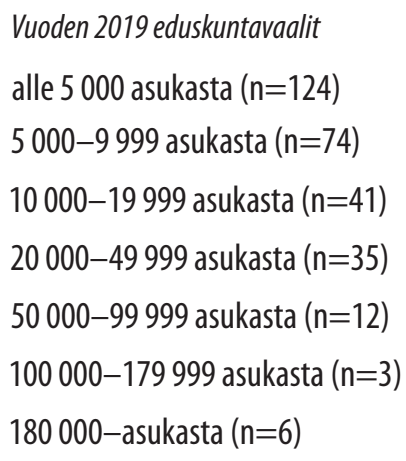

Vähintään 180000 asukkaan kaupungit muodostavat siis ainoan kuntakokokategorian, jossa äänestysprosentti nousi selkeästi sekä viime kuntavaaleissa että viime eduskuntavaaleissa niitä edeltäviin vaaleihin verrattuna. Julkisuudessakin on puhuttu siitä, miten suuri merkitys isoilla kaupungeilla on vaaleissa. Osin kyse on ollut siitä, että suurimmilla kaupungeilla on suurten äänimäärien vuoksi suuri vaikutus koko maan vaalitulokseen. Lisäksi suurimpien kaupunkien asukasluvut ovat kasvussa, kun taas monien pienempien kuntien asukasluvut ovat laskussa erityisesti ruuhka-Suomen ulkopuolella. Suurten kaupunkien äänioikeutettu väestö siis kasvaa suhteessa pienempien kuntien vastaavaan.

\section{SUURISSA KAUPUNGEISSA ANNETTUJEN ÄÄNTEN MÄÄRÄ KASVAA SUHTEESSA PIENEMPIIN KUNTIIN}

Taulukko 4 osoittaa annettujen äänien määrän ja niiden muutoksen kaksissa viime kuntavaaleissa Manner-Suomessa kuntakoon mukaan. Tämä havainnollistaa hyvin, miten paljon absoluuttisten äänien määrä kasvoi vuoden 2017 kuntavaaleissa kuudessa suurimmassa kaupungissa. 
Äänestysaktiivisuuden kasvu painottui erittäin vahvasti kuuteen suurimpaan kaupunkiin, joissa annettiin vuoden 2017 vaaleissa yhteensä lähes 90000 ääntä enemmän kuin vuonna 2012. Helsingissä annettiin 2017 noin 40000 ääntä enemmän kuin 2012. Espoossa ja Tampereella lisäys oli yli 10000 ja Vantaalla, Turussa ja Oulussa 8 000-9 000 ääntä.

Samanaikaisesti alle 5000 asukkaan kunnissa annettiin yli 12000 ääntä vähemmän ja 5000 9999 asukkaan kunnissa yli 11000 ääntä vähemmän 2012 vaaleihin verrattuna. Keskikokoisissa ja suurehkoissa kaupungeissa äänimäärä kasvoi myös, mutta maltillisesti isoimpiin kaupunkeihin verrattuna.

Taulukko 4. Annetut äänet vuosien 2017 ja 2012 kuntavaaleissa kuntakoon mukaan MannerSuomessa

\begin{tabular}{lccc}
\hline Kuntakoko & Annetut äänet & Annetut äänet & Erotus \\
\hline alle 5000 asukasta & 2017 & 2012 & \\
$5000-9999$ asukasta & 168288 & 180781 & -12493 \\
10000 -19 999 asukasta & 284731 & 296355 & -11624 \\
$20000-49$ 999 asukasta & 293875 & 297918 & -4043 \\
$50000-99$ 999 asukasta & 464168 & 458703 & 5465 \\
$100000-179$ 999 asukasta & 362264 & 358237 & 4027 \\
180000 - asukasta & 166116 & 157965 & 8151 \\
\hline Yhteensä & 831326 & 743565 & 87761 \\
\hline
\end{tabular}

Taulukko 5 osoittaa annettujen äänien määrän ja niiden muutoksen kaksissa viime eduskuntavaaleissa Manner-Suomessa kuntakoon mukaan. Tämäkin taulukko havainnollistaa absoluuttisten äänien määrän kasvua kuudessa suurimmassa kaupungissa vuoden 2019 eduskuntavaaleissa vuoden 2015 vaaleihin verrattuna. Suhteessa kuntavaalivertailuun annettujen äänien kasvu ei painotu kuitenkaan yhtä paljon suurimpiin kaupunkeihin.

Kuudessa suurimmassa kaupungissa annettiin noin 70000 ääntä enemmän vuoden 2019 vaaleissa vuoden 2015 vaaleihin verrattuna. 50 000-99 999 asukkaan kunnissa annettiin yli 40000 ääntä enemmän kuin vuonna 2015 ja 100 000-179 999 asukkaan kunnissakin (Lahti, Jyväskylä, Kuopio) yli 20000 ääntä enemmän. 
Taulukko 5. Annetut äänet vuosien 2019 ja 2015 eduskuntavaaleissa kuntakoon mukaan Manner-Suomessa

\begin{tabular}{lccc}
\hline Kuntakoko & $\begin{array}{c}\text { Annetut äänet } \\
2019\end{array}$ & $\begin{array}{c}\text { Annetut äänet } \\
2015\end{array}$ & Erotus \\
\hline alle 5000 asukasta & 195133 & 191532 & 3601 \\
5000 -9 999 asukasta & 301413 & 301363 & 50 \\
10000 -19 999 asukasta & 329820 & 366514 & -36694 \\
$20000-49$ 999 asukasta & 573439 & 566819 & 6620 \\
50000 -99 999 asukasta & 436869 & 394940 & 41929 \\
$100000-179$ 999 asukasta & 210849 & 189052 & 21797 \\
$180000-$ asukasta & 1007516 & 937173 & 70343 \\
\hline Yhteensä & 3055039 & 2947393 & 107646
\end{tabular}

Alle 5000 asukkaan kunnissa nousu oli maltillista (3 601 ääntä) ja toiseksi pienimmässä kokoluokassa (5 000-9 999 asukasta) annettujen äänien määrä pysyi lähes identtisenä. 10000 19999 asukkaan kunnissa annettiin noin 37000 ääntä vähemmän, mutta tämä johtuu pääosin siitä, että tässä kokokategoriassa kuntien määrä oli vähentynyt kuudella vuoteen 2019 tultaessa. Kaikkinensa taulukoiden 4 ja 5 päätulos on selkeä: annettujen äänien määrä kasvoi erittäin paljon suurimmissa kaupungeissa vuoden 2017 kuntavaaleissa ja vuoden 2019 eduskuntavaaleissa, minkä vuoksi niillä oli aiempaa suurempi merkitys myös koko maan vaalituloksen kannalta.

\section{KÄRKIEHDOKKAAT SAAVAT AIKAISEMPAA SUUREMMAN OSUUDEN ÄÄNISTÄ SUURIMMISSA KAUPUNGEISSA}

Äänten keskittyminen tunnetuille ehdokkaille on yksi osa politiikan henkilöitymiskehitystä (ks. Balmas ym. 2014; Karvonen 2010). Monet valtakunnallisesti tunnetut nimet ovat ehdolla vaaleissa suurimmista kaupungeista. Tämä on myös vahvistanut isojen kaupunkien asemaa vaalijulkisuudessa. Lisäksi kuntavaalitasolla Helsingissä oli ehdolla vuonna 2017 ehdokkaita, jotka kilpailivat pormestarin pestistä. Tampereella vastaavat niin sanotut pormestarivaalit on käyty vuodesta 2008 lähtien.

Taulukossa 6 tarkastellaan, mikä on ollut viiden suosituimman ehdokkaan ääniosuus kaikista annetuista äänistä kuudessa suurimmassa kaupungissa 2000-luvun kuntavaaleissa. Tämä tuo lisävaloa suurimpien kaupunkien äänestysprosentin muutokseen. Kuntavaaleissa asian tarkastelu on mielekkäämpää kuin eduskuntavaaleissa, koska kuntavaaleissa äänestäminen rajautuu luonnollisesti vain yhteen kuntaan. Eduskuntavaaleissa ehdokkaat käyvät Helsingin vaalipiiriä lukuun ottamatta kamppailua useiden kuntien äänistä. 
Taulukko 6 osoittaa, että suosituimpien ehdokkaiden suhteellinen yhteen laskettu äänipotti on kasvanut kaikissa suurimmissa kaupungeissa 2000-luvun aikana. Helsingissä on havaittavissa selkeä ero vuosien 2000-2012 ja vuoden 2017 vaalien välillä. Vuoden 2017 vaaleissa Helsingissä käytiin ensimmäistä kertaa niin kutsutut pormestarivaalit, minkä myötä kokoomuksen pormestariehdokas Jan Vapaavuori sai 29745 ääntä, vihreiden Anni Sinnemäki 8841 ääntä ja SDP:n Tuula Haatainen 7451 ääntä. Viiden eniten ääniä saaneen ehdokkaan prosenttiosuus kaikista äänistä nousi 11,1 prosentista 18,2 prosenttiin.

Taulukko 6. Viiden eniten ääniä keränneen ehdokkaan ääniosuus kaikista annetuista äänistä Suomen kuudessa suurimmassa kaupungissa 2000-luvun kuntavaaleissa (\%)

\begin{tabular}{llllll}
\hline & 2000 & 2004 & 2008 & 2012 & 2017 \\
\hline Helsinki & 12,3 & 11,7 & 10,7 & 11,1 & 18,2 \\
Espoo & 11,4 & 11,3 & 17,5 & 15,0 & 14,0 \\
Vantaa & 11,5 & 11,0 & 9,0 & 11,7 & 13,7 \\
Tampere & 14,9 & 11,8 & 17,2 & 11,6 & 16,4 \\
Turku & 14,0 & 11,6 & 12,4 & 11,6 & 18,0 \\
Oulu & 11,9 & 10,5 & 9,5 & 7,8 & 12,5
\end{tabular}

Myös Vantaalla, Turussa ja Oulussa ääniosuus oli vuoden 2017 vaaleissa korkeampi kuin kertaakaan aikaisemmin 2000-luvun aikana. Turussa osuus nousi samalle tasolle kuin Helsingissä - 18,0 prosenttiin - ja erityisen paljon ääniä sai Li Andersson (vas.): 6415 ääntä. Vantaalla ja Oulussa osuus on ollut kauttaaltaan hieman matalampi kuin muissa suurissa kaupungeissa, mikä johtuu osin siitä, että näissä kaupungeissa vetovoimaiset ehdokkaat, jotka olisivat hyvin tunnettuja valtakunnan politiikasta, ovat olleet harvemmassa.

Tampereella ja Espoossa viiden suosituimman ehdokkaan yhteenlaskettu ääniosuus on ollut toistaiseksi 2000-luvulla suurimmillaan vuoden 2008 vaaleissa. ${ }^{2}$ Kuitenkin myös näissä kaupungeissa ääniosuus oli 2017 suurempi kuin 2000-luvun kaksissa ensimmäisissä vaaleissa. Tampereella suosituin ehdokas vuoden 2017 vaaleissa oli Sanna Marin (sd.) 5783 äänellä ja Espoossa Kai Mykkänen (kok.) 4518 äänellä.

\section{SUURIMPIEN KAUPUNKIEN ÄÄNESTYSALUEILLA EI OLE HAVAITTAVISSA YHDENMUKAISTA ERIYTYMIS-TAI LÄHENTYMISTRENDIÄ ÄÄNESTYSAKTIIVISUUDESSA}

Tunnetut kärkiehdokkaat ja näkyvien poliittisen asetelmien rakentaminen - kamppailu siitä, mikä puolue saa kaupungissa eniten valtaa - voivat tietyiltä osin lisätä äänestysaktiivisuutta suurissa kaupungeissa, mutta ne eivät selitä ilmiötä millään lailla tyhjentävästi. Huomiota on kiinnitettävä myös kaupunkien sisäiseen äänestysaktiivisuuteen ja sen kehitykseen. Erot suurimpien 
kaupunkien eri äänestysalueiden äänestysaktiivisuudessa ovat erittäin suuria. Ero korkeimman ja matalimman äänestysprosentin äänestysalueen välillä oli vuoden 2017 vaaleissa 40 prosenttiyksikön tietämissä Helsingissä ja Espoossa sekä noin 30 prosenttiyksikköä Vantaalla, Turussa, Tampereella ja Oulussa. (Borg 2017, 74.)

Taulukossa 7 on tarkasteltu äänestysaktiivisuutta äänestysaluetasolla kuudessa suurimmassa kaupungissa vuosien 2012 ja 2017 kuntavaaleissa. Äänestysprosentti nousi koko kaupungin tasolla eniten Helsingissä, Turussa ja Tampereella. Näistä kaupungeista Helsingissä äänestysprosentin keskihajonta äänestysaluetasolla oli jonkin verran suurempi vuonna $2017(8,92)$ kuin vuonna $2012(8,34)$. Tampereellakin hajonta kasvoi, mutta Turussa muutosta ei käytännössä ollut lainkaan.

Taulukko 7. Äänestysaktiivisuus äänestysaluetasolla Suomen kuudessa suurimmassa kaupungissa vuosien 2012 ja 2017 kuntavaaleissa (\%)

\begin{tabular}{lccccc}
\hline & $\begin{array}{c}\text { Äänestysprosentti } \\
\text { koko kaupungissa }\end{array}$ & Minimi & Maksimi & Keskihajonta & $\begin{array}{c}\text { Äänestysalueet } \\
\text { (N) }\end{array}$ \\
\hline Helsinki 2012 & 57,4 & 36,8 & 76,7 & 8,34 & 157 \\
Helsinki 2017 & 61,6 & 41,1 & 81,2 & 8,92 & 165 \\
Espo0 2012 & 59,3 & 37,4 & 75,5 & 8,12 & 67 \\
Espoo 2017 & 60,1 & 37,4 & 76,4 & 8,11 & 69 \\
Vantaa 2012 & 51,0 & 37,1 & 64,8 & 7,35 & 64 \\
Vantaa 2017 & 52,3 & 39,1 & 67,4 & 7,69 & 64 \\
Turku 2012 & 55,6 & 38,9 & 74,1 & 6,80 & 54 \\
Turku 2017 & 59,0 & 42,5 & 74,3 & 6,83 & 49 \\
Tampere 2012 & 56,3 & 41,5 & 70,6 & 5,92 & 63 \\
Tampere 2017 & 59,3 & 42,8 & 72,1 & 6,16 & 67 \\
Oulu 2012 & 53,7 & 38,5 & 65,2 & 5,70 & 57 \\
Oulu 2017 & 55,9 & 36,7 & 67,1 & 5,41 & 55
\end{tabular}

Espoossa, Vantaalla ja Oulussa äänestysprosentin kasvu oli maltillisempaa koko kaupungin tasolla. Espoossa keskihajonta äänestysalueiden äänestysprosentissa säilyi identtisenä, Oulussa se pieneni ja Vantaalla suureni jonkin verran. Kokonaisuudessaan voidaan siis todeta, että Helsingissä äänestysprosentin voimakas nousu kasvatti myös eroja eri äänestysalueiden välillä, ja ne kasvoivat hieman myös Tampereella ja Vantaalla. Yhtenäistä äänestysaluetason mukaista eriytymis- tai lähestymistrendiä ei kuitenkaan nähty vuoden 2017 vaaleissa kuudessa suurimmassa kaupungissa. 


\section{VIHREÄT, KOKOOMUS JA VASEMMISTOLIITTO NOJAAVAT SUURTEN KAUPUNKIEN KANNATUKSEEN}

Äänestysaktiivisuuden ohella analysoidaan lopuksi puolueiden kannatusta edellä tarkastelluissa kuntakokoryhmissä. Puolueiden kannatus vaihtelee voimakkaasti paitsi alueittain (ks. Grönlund ja Westinen 2012; Paloheimo ja Sundberg 2005; Westinen 2014) myös kuntakoon mukaisesti maantieteestä riippumatta. Taulukoissa 8 ja 9 näkyy asukaslukuun perustuvien kuntaryhmien ääniosuus kunkin eduskuntapuolueen ${ }^{3}$ koko maan äänistä vuosien 2012 ja 2017 vaaleissa. Niiden perusteella voidaan arvioida, kuinka vahvasti kunkin puolueen kannatus nojautuu tietyn kokoisiin kuntiin. Kuntakokokategoriat ovat samat kuin edellä analysoiduissa taulukoissa.

Taulukko 8. Asukaslukuun perustuvien kuntaryhmien ääniosuus kunkin eduskuntapuolueen koko maan äänistä vuoden 2012 kuntavaaleissa (\%)

\begin{tabular}{lcccccccc}
\hline Kuntakok0 & KOK & SDP & KESK & VIHR & PS & VAS & RKP & KD \\
\hline Alle 5 000 asukasta & 4,4 & 5,1 & 17,6 & 1,0 & 8,1 & 5,2 & 2,0 & 5,7 \\
Väh. 5000, alle 10 000 asukasta & 8,3 & 10,0 & 20,9 & 3,2 & 11,0 & 10,8 & 22,7 & 9,9 \\
Väh. 10 000, alle 20 000 asukasta & 10,2 & 11,5 & 16,1 & 5,4 & 11,7 & 9,9 & 20,6 & 13,7 \\
Väh. 20 000, alle 50 000 asukasta & 18,5 & 21,0 & 16,7 & 14,0 & 18,7 & 20,2 & 12,3 & 22,0 \\
Väh. 50 000, alle 100 000 asukasta & 15,2 & 16,7 & 12,8 & 10,2 & 16,4 & 12,1 & 11,9 & 17,4 \\
Väh. 100 000 asukasta, alle 180 000 as. & 6,6 & 7,8 & 5,4 & 6,0 & 6,9 & 6,4 & 0,0 & 9,9 \\
Väh. 180 000 asukasta & 36,8 & 27,9 & 10,7 & 60,1 & 27,1 & 35,5 & 30,5 & 21,3 \\
\hline Yhteensä & 100 & 100 & 100 & 100 & 100 & 100 & 100 & 100
\end{tabular}

Taulukko 9. Asukaslukuun perustuvien kuntaryhmien ääniosuus kunkin eduskuntapuolueen koko maan äänistä vuoden 2017 kuntavaaleissa (\%)

\begin{tabular}{lcccccccc}
\hline Kuntakoko & KOK & SDP & KESK & VIHR & PS & VAS & RKP & KD \\
\hline Alle 5 000 asukasta & 4,1 & 5,0 & 16,9 & 1,2 & 7,0 & 4,5 & 1,8 & 5,4 \\
Väh. 5000, alle 10000 asukasta & 7,6 & 9,7 & 20,1 & 3,5 & 10,1 & 10,1 & 21,6 & 10,2 \\
Väh. 10 000, alle 20 000 asukasta & 9,2 & 11,4 & 16,4 & 5,8 & 12,1 & 9,2 & 21,1 & 13,5 \\
Väh. 20 000, alle 50 000 asukasta & 17,3 & 21,8 & 16,9 & 15,2 & 19,5 & 19,3 & 12,0 & 20,4 \\
Väh. 50 000, alle 100000 asukasta & 14,4 & 17,4 & 13,1 & 11,8 & 15,4 & 11,4 & 13,7 & 16,2 \\
Väh. 100 000 asukasta, alle 180 000 as. & 6,3 & 7,6 & 5,6 & 7,8 & 6,7 & 6,4 & 0,1 & 9,7 \\
Väh. 180 000 asukasta & 41,1 & 27,0 & 11,1 & 54,8 & 29,1 & 39,2 & 29,7 & 24,6 \\
\hline Yhteensä & 100 & 100 & 100 & 100 & 100 & 100 & 100 & 100
\end{tabular}


Taulukot osoittavat, että kaksien viime kuntavaalien välillä ei ole tapahtunut suuria muutoksia sen suhteen, kuinka suuri painoarvo minkäkin kokoisilla kunnilla on kunkin puolueen kokonaiskannatuksessa. Joitakin mielenkiintoisia poikkeuksia silti on. Suurimpien kaupunkien (vähintään 180000 asukasta) painoarvo kasvoi vuoden 2017 vaaleissa kokoomuksen ja vasemmistoliiton koko maan äänipotissa. Kokoomuksen kaikista äänistä suurimmat kaupungit muodostivat vuoden 2017 vaaleissa 41,1 prosenttia (+4,3 prosenttiyksikköä). Vasemmistoliiton kaikista äänistä suuret kaupungit muodostivat vuoden 2017 vaaleissa 39,2 prosenttia $(+3,7$ prosenttiyksikköä). Vasemmistoliiton kohdalla mielenkiintoista on, että puolueen kannattajakunnassa on tapahtunut paitsi arvopohjainen muutos kohti yhä vahvempaa arvoliberaaliutta myös muutos kohti urbaanimpaa ja eteläisempää kannattajakuntaa (ks. Westinen 2016; vrt. Paloheimo \& Sundberg 2005).

Vihreät nojaa kaikkein eniten suuriin kaupunkeihin, sillä 54,8 prosenttia puolueen äänistä tuli niistä vuoden 2017 vaaleissa. Osuus tosin laski 2012 vaaleista, koska vuoden 2017 vaaleissa vihreät teki historiansa parhaimman kuntavaalituloksen ja menestyi aikaisempaa paremmin myös suurten kaupunkien ulkopuolella. On silti syytä huomioida, että vihreiden äänipotti kasvoi kuitenkin vajaalla 50000 äänellä suurimmissa kaupungeissa.

Taulukot 8 ja 9 osoittavat myös, että keskustan kannatuksesta vain hieman yli 10 prosenttia tulee suurimmista kaupungeista ja lähes 40 prosenttia alle 10000 asukkaan kunnista. Osuudet ovat hyvin poikkeavia muihin puolueisiin verrattuna. SDP:n ja perussuomalaisten äänipottien jakautuminen kuntakokoryhmiin on puolestaan keskenään hyvin samankaltaista: niiden suhteellisesti vahvin ryhmä on keskisuuret kaupungit (20 000-49 999 asukasta).

Tulokset osoittavat, että äänestysaktiivisuuden muutoksilla on merkitystä myös puoluekannatukselle. Jos suurimpien kaupunkien äänestysaktiivisuus kasvaa tulevaisuudessa ja pienten kuntien äänestysaktiivisuus laskee tai pysyy entisellään, se on omiaan hyödyttämään vihreitä, kokoomusta ja vasemmistoliittoa, joiden kannatus nojaa vahvimmin suuriin kaupunkeihin. Vastaavasti kehitys on epäsuotuisaa erityisesti keskustalle, jolle menestyminen isoimmissa kaupungeissa on ollut vaikeaa.

\section{YHTEENVETO}

Äänestysaktiivisuuden nousu oli viime kuntavaaleissa (2017) erityisen vahvaa suurimmissa, vähintään 180000 asukkaan kaupungeissa. Myös eduskuntavaaleissa äänestysaktiivisuus nousi viime vaaleissa (2019) selkeimmin juuri suurimmissa kaupungeissa. Suurimmissa kaupungeissa oli kasvua vajaat 90000 ääntä kuntavaaleissa ja noin 70000 ääntä eduskuntavaaleissa edellisiin vaaleihin verrattuna. Samalla erityisesti pienimmissä, alle 5000 asukkaan kunnissa äänestysaktiivisuus laski viime kuntavaaleissa ja jäi eduskuntavaaleissa lähes ennalleen.

Suurten kaupunkien korostumista tukee muun muassa äänestysaktiivisuuden kietoutuminen sosioekonomisiin tekijöihin (ks. Bengtsson 2004; Westinen ja Borg 2016): korkealla koulutustasolla ja matalalla työttömyydellä on äänestysprosenttia nostattava vaikutus. Lisäksi suurissa kaupungeissa on usein ehdolla laajaa tunnettavuutta nauttivia ehdokkaita, ja suurten kaupunkien asiat ja valtakamppailut korostuvat vaalien mediajulkisuudessa. Viiden suosituimman ehdokkaan osuus kaikista äänistä on kasvanut 2000-luvulla Helsingissä, Espoossa, 
Vantaalla, Turussa, Tampereella ja Oulussa eli kaikissa Suomen suurimmissa kaupungeissa. Vain Helsingissä ja Tampereella on käyty kuntavaalien yhteydessä pormestarikisaa, joten kehitys ei selity vain tämänkaltaisilla kaupunkien johtoa koskevilla uudistuksilla.

Kuntavaaleissa äänestysaktiivisuus on ollut pääsääntöisesti sitä korkeampi, mitä pienemmästä kunnasta on kyse. Erot tasoittuvat vuoden 2017 vaaleissa. Eduskuntavaaleissa huomattavaa tilastollista yhteyttä ei ole ollut, mutta viimeisimmät muutokset ovat samankaltaisia kuin kuntavaaleissa - suurten kaupunkien suhteellinen merkitys kasvaa ja pienten kuntien pienenee. Suurten kaupunkien merkitys ei selity vain muuttoliikkeellä, joka suuntautuu isoihin kaupunkeihin ja niiden läheisyyteen pientenkin kuntien kustannuksella (Tilastokeskus 2021b). Paitsi äänioikeutettujen, myös äänestäneiden määrä kasvaa.

Äänestysaktiivisuus eriytyy paitsi erikokoisten kuntien välillä myös niiden sisällä. Erityisesti suurissa kaupungeissa on hyvin suuret erot eri äänestysalueiden välillä, ja ne noudattelevat hyvin pitkälti sosioekonomisia tulo- ja koulutustason mukaisia eroja. Hyväosaisilla alueilla äänestetään huono-osaisia alueita aktiivisemmin aivan kuten yksilötasolla hyväosaiset äänestävät huono-osaisia aktiivisemmin. Vuoden 2017 kuntavaaleissa ei ollut kuittenkaan kauttaaltaan havaittavissa, että äänestysprosentin kasvu olisi tullut yksinomaan sen kautta, että erot olisivat revenneet entisestään äänestysalueiden välillä isoimmissa kaupungeissa. Myös monilla alueilla, joiden sosioekonomisen status on matala, äänestysaktiivisuus nousi.

Tulevat vaalit näyttävät, jatkuuko samankaltainen kehityskulku. Kesäkuun 2021 kuntavaalit ovat poikkeukselliset siinä mielessä, että niitä siirrettiin noin kahdella kuukaudella eteenpäin alkuperäisestä vaaliaikataulusta koronapandemian vuoksi. Paitsi vaalien ajankohdan siirrolla, myös itse koronatilanteella ja sen alueellisella vaihtelevuudella voi olla vaikutuksia äänestysaktiivisuuteen.

Koronatilanne on ollut korostuneen huono pääkaupunkiseudulla, kun taas kymmenissä pikkukunnissa on ollut alle 20 tartuntaa koko korona-aikana. Tartuntojen suhteutettu osuus kunnanasukaslukuun osoittaa, että tilanne on ollut huonoin isoissa kaupungeissa: myös Turussa ja Tampereella tartuntatilanne on ollut haastava. (Terveyden ja hyvinvoinnin laitos 2021.) Koronaturvallisen äänestämisen helpottamiseksi kesäkuun vaaleihin kehitetään drive-in-äänestyksiä ja konttiäänestyksiä erityisesti isoimmissa kaupungeissa. Myös turvavälejä ja muita järjestelyitä tehdään mahdollisimman paljon äänestyspaikoilla.

Yksi skenaario on, että kuntavaaleissa jäädään korontartuntojen pelossa herkemmin kotiin ja jätetään äänestämättä nimenomaan isoimmissa kaupungeissa, joissa äänestysaktiivisuus on viime vaalien noususta huolimatta ollut alle koko maan keskiarvon ja joissa on lukuisilla äänestysalueilla jo entuudestaan välinpitämättömyyttä kuntavaaleista. Toinen skenaario on, että pienissä maaseutumaisissa kunnissa, joissa iäkkään väestön osuus on suuri, jätetään aikaisempaa enemmän äänestämättä. Vaikka eläkeikäinen väestö, jolle korona on korostunut terveysuhka, on pitkälti rokotettu vaaleihin mennessä, voi pelko yhä estää ihmisiä liikkumasta muuten kuin aivan välttämättömissä tarkoituksissa. Kolmas skenaario on, että äänestysaktiivisuuden muutoksella ja kuntakohtaisella koronatilanteella ei ole vaaleissa yhteyttä, vaan äänestyspäätökseen vaikuttavat aivan muut tekijät. 


\section{VIITTEET}

1. Vantaalla on ollut suurimmista kaupungeista selkeästi alhaisin äänestysprosentti. Se oli kuntatasolla koko maan alhaisin (51,0 \%) vuoden 2012 vaaleissa ja neljänneksi alhaisin (52,3 \%) vuoden 2017 vaaleissa. Verrattuna Helsinkiin ja Espooseen Vantaalla on vähemmän hyvätuloisia asukkaita, jolla on keskimääräistä korkeampi äänestystodennäköisyys. (Ks. Espoon kaupunki 2020; Vantaan kaupunki 2019.)

2. Tampereella ääniosuutta nosti paitsi ensimmäiset niin sanotut pormestarivaalit, myös Marjatta Stenius-Kaukosen (vas.) paluu ehdolle vaaleihin. Hän sai lähes 6000 ääntä ja oli selkeästi koko kaupungin suosituin ehdokas. Espoossa puolestaan Timo Soini (ps.) sai äänivyöryn - yli 8000 ääntä - ja oli ylivoimaisesti Espoon suosituin ehdokas.

3. Pois lukien Liike Nyt, joka asetti vaaleihin ehdokkaita ensimmäisen kerran vasta vuoden 2019 eduskuntavaaleissa.

\section{LÄHTEET}

Balmas, Meital, Rahat, Gideon, Sheafer, Tamir ja Shenhav, Saul R. 2014. Two routes to personalized politics: Centralized and decentralized personalization. Party Politics 20:1, 37-51.

Bengtsson, Åsa. 2004. Valdeltagande i Finland. Rationalitet eller socialt tryck? Politiikka 46:1, 3-16.

Borg, Sami. 1996. Velvollisuus vaikuttaa. Tutkimus suomalaisten äänestysosallistumisen perusteista ja eduskuntavaalien äänestysprosentin laskusta. Acta Universitatis Tamperensis, A 491. Tampere: Tampereen yliopisto.

Borg, Sami. 2017. Kuntavaalitutkimus. Helsinki: Kunnallisalan Kehittämissäätiö.

Borg, Sami ja Pikkala, Sari. 2017. Kuntavaalitrendit. Helsinki: Kunnallisalan Kehittämissäätiö.

Espoon kaupunki. 2020. Espoo alueittain 2019. Raportteja Espoosta 2:2020.

Grönlund, Kimmo ja Westinen, Jussi. 2012. Puoluevalinta. Teoksessa Sami Borg (toim.), Muutosvaalit 2011. Helsinki: Oikeusministeriö, 156-187. https://julkaisut.valtioneuvosto.fi/handle/10024/76355

Karvonen, Lauri. 2010. The personalisation of politics: A study of parliamentary democracies. Colchester: ECPR Press.

Paloheimo, Heikki ja Sundberg, Jan. 2005. Puoluevalinnan perusteet. Teoksessa Heikki Paloheimo (toim.), Vaalit ja demokratia Suomessa. Porvoo: WSOY, 169-201.

Pikkala, Sari. 2015. Kuntavaalit ja kuntarakenteen muutos. Paras-ARTTU-ohjelman tutkimuksia nro 32. Helsinki: Suomen Kuntaliitto.

Terveyden ja hyvinvoinnin laitos. 2021. Varmistetut koronatapaukset Suomessa (COVID-19). https:// experience.arcgis.com/experience/d40b2aaf08be4b9c8ec38de30b714f26. Viitattu 27.4.2021.

Tilastokeskus. 2021a. Vaalit. https://pxnet2.stat.fi/PXWeb/pxweb/fi/StatFin/StatFin_vaa. Viitattu 27.4.2021.

Tilastokeskus 2021b. Väestörakenne. Tunnuslukuja väestöstä alueittain, 1990-2020. https://pxnet2.stat. fi/PXWeb/pxweb/fi/StatFin/StatFin_vrm_vaerak/statfin_vaerak_pxt_11ra.px/.Viitattu 27.4.2021.

Vantaan kaupunki. 2019. Väestön koulutusrakenne Vantaalla. Tilastokatsaus 2:2019. https://www.vantaa.fi/instancedata/prime_product_julkaisu/vantaa/embeds/vantaawwwstructure/144222_Tilasto- 
katsaus_2_2019_Vaeston_koulutusrakenne_Vantaalla.pdf. Viitattu 12.5.2021

Wass, Hanna. 2008. Generations and turnout. The generational effect in electoral participation in Finland. Acta Politica 35. Helsinki: Department of Political Science, University of Helsinki.

Wass, Hanna ja Borg, Sami. 2012. Äänestysaktiivisuus. Teoksessa Sami Borg (toim.), Muutosvaalit 2011. Oikeusministeriön julkaisu; OMSO 16/2012. Helsinki: Oikeusministeriö, 97-115. http://urn.fi/ URN:ISBN:978-952-259-172-2

Wass, Hanna ja Borg, Sami. 2016. Yhdenvertaisuus äänestyskopissa. Äänestysaktiivisuus vuoden 2015 eduskuntavaaleissa. Teoksessa Kimmo Grönlund ja Hanna Wass (toim.), Poliittisen osallistumisen eriytyminen. Eduskuntavaalitutkimus 2015. Helsinki: Oikeusministeriö, 177-199.

Westinen, Jussi. 2014. True Finns: A Shock for Stability? Testing the Persistence of Electoral Geography in Volatile Elections. Scandinavian Political Studies 37:2, 123-148.

Westinen, Jussi. 2016. Puoluevalinta Suomessa 2000-luvulla. Teoksessa Kimmo Grönlund ja Hanna Wass (toim.), Politttisen osallistumisen eriytyminen. Eduskuntavaalitutkimus 2015. Helsinki: Oikeusministeriö, 249-272.

Westinen, Jussi ja Borg, Sami. 2016. Itä-Suomen vaalipiiriuudistuksen vaikutukset. Teoksessa Kimmo Grönlund ja Hanna Wass (toim.), Poliittisen osallistumisen eriytyminen. Eduskuntavaalitutkimus 2015. Helsinki: Oikeusministeriö, 200-223.

\section{KIRJOITTAJATIEDOT}

JUSSI WESTINEN

VTT, tutkija

E2 Tutkimus

jussi.westinen@e2.fi 